\title{
PERBANDINGAN MOTIVASI BELAJAR SISWA ANTARA BELAJAR MELALUI BIMBEL TATAP MUKA DAN BELAJAR MELALUI BIMBEL DARING DENGAN APLIKASI RUANG GURU SMA NEGERI KOTA BENGKULU
}

\author{
Intan Paramika, I Wayan Dharmayana, Illawaty Sulian \\ Prodi Bimbingan dan Konseling Fakultas Keguruan dan Ilmu Pendidikan \\ Universitas Bengkulu \\ intanparamika@gmail.com, dharmayana@unib.ac.id, $\underline{\text { illawaty@unib.ac.id }}$
}

\begin{abstract}
ABSTRAK
Penelitian ini bertujuan untuk mengetahui perbandingan motivasi belajar siswa antara bimbingan belajar tatap muka dan bimbingan belajar daring dengan aplikasi ruang guru di SMA Negeri 1 Kota Bengkulu. Subjek penelitian ini adalah seluruh kelas XI dan XII SMA Negeri 1 Kota Bengkulu, dengan sampel yang digunakan berjumlah 239 siswa. Pengambilan sampel dilakukan secara random. Metode penelitian yang digunakan adalah metode deskriptif kuantitatif, dengan tipe desain penelitian deskriptif komparatif. Variabel motivasi belajar siswa diukur dengan menggunakan motivasi belajar. Hasil penelitian menunjukkan nilai rata-rata bimbingan belajar tatap muka adalah 124,81 dan bimbingan belajar daring adalah 111,62 . Sedangkan nilai $t=4,775$ dengan taraf signifikan $0,000(\mathrm{p}<$ 0,05). Ini berarti ada perbedaan motivasi belajar belajar melalui bimbingan belajar tatap muka dengan bimbingan belajar daring yang signifikan antara belajar melalui bimbingan belajar tatap muka dan bimbingan belajar daring melalui aplikasi ruang guru.
\end{abstract}

Kata Kunci: Motivasi Belajar siswa, Bimbel Tatap Muka, Bimbel Daring, Aplikasi Ruang Guru

\section{THE COMPARISON OF THE STUDENT LEARNING BETWEEN LEARNING WITH FACE TO FACE TUTORING AND LEARNING THROUGH ONLINE TUTORING WITH THE RUANG GURU APPLICATION IN SMA BENGKULU CITY}

\begin{abstract}
This study aims to determine the comparison of student learning motivation between face to face tutoring and online tutoring with the ruang guru aplication in SMA Country 01 Bengkulu City. The subjects of this study were all grades XI and XII SMA Country 01 Bengkulu City, with the sample used totaled 239 students. Sampling is done ramdomly. The research method used is descriptive quantitative method, with a comparative descriptive research design type. The student learning motivation variables is measured using learning motivation. The result showed the average value of face to face tutoring is 124,81 and online tutoring is 111,62 . While the value of $\mathrm{t}=4,775$ to a significant degree $0,000(\mathrm{p}<$ 0,05). This means that there is a difference in learning motivation to learn throgh face to face tutoring with online tutoring significant difference between face to face tutoring and online tutoring through the teacher room application.
\end{abstract}

Keywords: Student Learning Motivation, Face to Face Tutoring, Online Tutoring, Ruang Guru Application. 


\section{PENDAHULUAN}

Pendidikan adalah suatu pembelajaran yang diberikan kepada peserta didik dan hasil untuk menghasilkan kompetensinya. Pembelajaran yang diberikan dapat berupa bimbel untuk mengembangkan dan memotivasi pembelajaran siswa. Setiawati (2019:241) mengungkapkan pendidikan adalah usaha orang secara sadar untuk mengembangkan kepribadian, membimbing kemampuan karakter dan pendidikan anak, baik dalam pendidikan formal maupun pendidikan non formal. Undang-undang sistem pendidikan nasional No. 20 Tahun 2003 mengungkapkan bahwa pendidikan adalah usaha sadar dan terencana untuk mewujudkan suasana belajar dan proses pembelajaran agar peserta didik dapat secara aktif mengembangkan potensi (Siregar, 2016:49). Lalo (2018:68) menjelaskan pendidikan merupakan bagian dari globalisasi,yang mempengaruhi penyebaran dalam gagasan,pembaharuan dan inovasi dalam struktur, isi dan metode pendidikan dan pembelajaran.

Salah satu fenomena penting dalam proses globalisasi adalah terlahirnya generasi gadget, yaitu yang digunakan untuk menandakan munculnya generasi millennial. Gadget sebenarnya cocok diartikan dengan peralatan, artinya generasi gedget dikelompokkan dengan generasi yang dalam kehidupannya selalu bersinggungan dengan namanya peralatan yang mengandung unsur teknologi informasi. Sehingga peralatan tersebut telah menjadi bagian penting yang tak terpisahkan dari kehidupan. Artinya dapat dikatakan high teknologi telah menjadi bagian dalam kehidupannya sehari-hari (Wahana, 2015:14). Generasi saat ini disebut dengan generasi millennial, yaitu generasi yang lahir antara tahun 1980 sampai 2000-an. Era millennial ialah masa adanya peningkatan penggunaan dan keakraban dengan komunikasi, media dan teknologi digital seperti saat ini. Generasi yang hidup di era millennial ini memiliki karakter yang khas. Sejak di bangku sekolah sudah menggunakan internet sebagai kebutuhan pokok. Di era globalisasi ini, semakin banyak tantangan dalam setiap sisi. Baik dalam dunia kerja, kehidupan sehari - hari atau dunia pendidikan (Putri, 2017:45).

Penggunaan teknologi yang semakin berkembang menjadi semakin penting didalam kehidupan, karena dapat menjadi pemicu motivasi belajar peserta didik, sehingga mereka memiliki keterampilan belajar yang berinovasi. Keterampilan menggunakan teknologi digital membantu lebih cepat dapat mendapatkan informasi serta meningkatkan life skills sebagai modal kerja dan pendidikan dengan mudah mengembakan bahan pelajaran. (Muhasim, 2017:53). 
Siregar (2016:49), mengungkapkan motivasi belajar siswa adalah dorongan dan kebutuhan dalam belajar, yang memiliki ciri tekun mengerjakan tugas, tahan menghadapi kesulitan, senang belajar mandiri, percaya pada kemampuan, senang mencari dan memecahkan soal- soal, sehingga belajar menjadi hal yang menarik dan terjadi perlombaan di lingkungan belajar, untuk mencapai keberhasilan siswa dalam pembelajaran. Dengan demikian motivasi diartikan sebagai suatu tenaga atau faktor yang terdapat dalam diri manusia yang menimbulkan, mengarahkan dan mengorganisasikan tingkah lakunya sedangkan belajar adalah suatu usaha sadar yang dilakukan oleh individu dalam perubahan tingkah laku baik melalui latihan dan pengalaman yang menyangkut aspek-aspek kognitif, afektif dan psikomotor untuk memperoleh tujuan tertentu (Emda, 2017:93).

Motivasi belajar siswa dapat mempengaruhi prestasi yang dicapainya dikarenakan untuk dapat mencapai hasil belajar yang optimal, siswa dituntut untuk mampu bekerja secara keras dan secara cerdas dalam setiap aktifitasnya, dan untuk memiliki kedua kemampuan tersebut siswa harus memiliki motivasi belajar yang tinggi. Motivasi belajar penting bagi siswa dalam mengikuti proses pembelajaran, karena motivasi belajar tersebutlah yang akan menggerakkan siswa dalam memilih tindakan dan tujuan belajar yang dirasa paling berguna bagi kehidupan siswa (Silondae, 2019:1).

Arimbawa, Satyayasa, \& Rapi (2017:43) mengungkapkan motivasi menunjuk pada kondisi yang beragam seperti : keinginan (desires), harapan (wishes), rencana (plans), sasaran (goals), niat (intent) impuls dan tujuan (purpose). Dengan demikian, dengan adanya sebuah motivasi belajar maka siswa diharapkan untuk dapat menggerakkan keinginan belajar mereka secara maksimal, sehingga mereka yang memiliki motivasi belajar yang tinggi akan semaksimal mungkin untuk mendapatkan prestasi belajar yang optimal. Selain motivasi, strategi pembelajaran secara langsung juga memengaruhi pencapaian prestasi belajar siswa.

Wahana (2015:14), mengungkapkan strategi pembelajaran era globalisasi mempunyai pengaruh yang sangat signifikan terhadap pola pembelajaran yang mampu memberdayakan para peserta didik. Tuntutan global telah mengubah paradigma pembelajaran dari paradigma pembelajaran tradisional ke paradigma pembelajaran modern.

Lembaga bimbingan belajar (LBB) atau sering disingkat bimbel menjamur di manamana, baik yang dikelola perorangan maupun kelompok, mulai dari privat sampai dengan proses pembelajaran di Ruko yang ber AC. Hingga kini masih banyak tempat- tempat bimbingan belajar dengan nama baru bermunculan dengan menawarkan berbagai macam program unggulan (Apriliani \& Wahyudi, 2017:1). 
Wardani (2012:68) mengungkapkan bimbingan belajar saat ini masih menjadi pilihan bagi para pelajar untuk memperluas pengetahuan dan menambah jam belajar serta menjadikannya sebagai media untuk belajar bersama teman dan berinteraksi dengan guru dalam kondisi yang lebih santai.

Bimbingan belajar adalah suatu proses pemberian bantuan yang ditunjukkan kepada individu atau kelompok siswa agar yang bersangkutan dapat mengenali dirinya sendiri, baik kemampuan yang dimilikinya maupun kelemahannya agar selanjutnya dapat mengambil keputusan dan dapat bertanggung jawab dalam menentukan jalan hidupnya atau memecahkan sendiri kesulitan yang dihadapi serta dapat memahami lingkungannya secara tepat sehingga dapat memperoleh kebahagiaan hidupnya (Elsap, 2018:85).

Pada era globalisasi saat ini, teknologi informasi dan komunikasi sangat berkembang pesat, terutama pada bidang pendidikan. Generasi millenial sebagian besar merupakan pelajar SMP dan SMA lebih banyak menghabiskan waktunya dengan gadget. Salah satu media pembelajaran daring saat ini, salah satunya Ruang Guru (Dian \& Soedarsono, 2019:1).

Syafril (2019:94) mengungkapkan perusahaan Ruang Guru dirikan sejak tahun 2014 oleh Belva Devara dan Iman Usman, yang keduanya berhasil masuk dalam jajaran pengusaha sukses di bawah 30 tahun melalui Forbes 30 under 30 untuk teknologi konsumen di Asia. Ruang guru berkomitmen untuk menjadi mitra bagi pemerintah daerah learning management sistem memberikan pendidikan berkualitas melalui Sistem Manajemen Belajar (LMS). Tahun lalu, Ruang Guru berhasil bekerja sama dengan 32 dari 34 pemerintah provinsi dan lebih dari 326 pemerintah kota dan kabupaten di Indonesia. Selain itu, ruang guru juga menawarkan video belajar berlangganan, market place les privat, layanan bimbingan belajar on- demand, tryout ujian online, dan lain-lain.

Agustini, Irwan, \& Khairurahim (2017:174) mengungkapkan kebanyakan pelajar masa kini sulit memahami pelajaran yang didapatkan di sekolah sehingga ketika di rumah mereka sibuk dengan gadget masing-masing dan melupakan pelajaran yang dipelajari di sekolah oleh karena itu diperlukan pelajaran tambahan yang dapat diakses melalui smarphone, tablet atau laptop, dalam hal ini bimbingan belajar online.

Syamsurijal (2019) menjelaskan bahwa Ruang Guru hadir sebagai salah satu alternatif bimbel online yang dapat dengan mudah diakses melalui smartphone, laptop atau pun tablet. Beberapa fitur unggulan seperti Ruang Uji, Ruang Latihan, Ruang Video, Ruang Les, Ruang Les Online, Digital Boot Camp dan Edumail memungkinkan siswa untuk mengupgrade kemampuan belajarnya sehingga diharapkan dapat mencapai hasil yang 
diinginkan.

Menurut informasi yang didapatkan dari instagram Ruang Guru, bahwasannya siswa di sekolah SMA Negeri 1 Kota Bengkulu banyak yang mengetahui bimbel daring di aplikasi ruang guru. Selain itu, dikarenakan banyak yang bimbel daring di sekolah ini, sehingga dapat membandingkan bagaimana motivasi belajar tatap muka dengan belajar melalui bimbel seperti Ganesha Operation, Primagama dan melalui ruang guru.

Bimbel daring memiliki kelebihan yaitu 1) Penyampaian pembelajaran dapat dilaksanakan kapan saja dan dimana saja dengan memanfaatkan sistem jaringan internet, 2) Peserta didik memiliki keleluasan untuk mempelajari materi atau bahan ajar secara mandiri dengan memanfaatkan bahan ajar yang tersimpan secara online, 3) Kegiatan diskusi berlangsung secara online dan berlangsung diluar jam pelajaran, kegiatan diskusi berlangsung baik antara peserta didik dengan guru maupun antara antar peserta didik itu sendiri, 4) Pengajar dapat mengelola dan mengontrol pembelajaran yang dilakukan siswa diluar jam pelajaran peserta didik, 5) Pengajar dapat meminta kepada peserta didik untuk mengkaji materi pelajaran sebelum pembelajaran berlangsung dengan menyiapkan tugastugas pendukung, 6) Target pencapaian materi-materi ajar dapat dicapai sesuai dengan target yang ditetapkan, 7) Pembelajaran menjadi luwes dan tidak kaku. Selanjutnya, kelemahan dari bimbel daring yaitu 1) Pengajar perlu memiliki keterampilan dalam menyelenggarakan e-learning, 2) Pengajar perlu menyiapkan waktu untuk mengembangkan dan mengelola pembelajaran sistem e-learning, seperti mengembangkan materi, menyiapkan assesment, melakukan penilaian, serta menjawab atau memberikan pernyataan pada forum yang disampaikan oleh peserta didik, 3) Pengajar perlu menyiapkan referensi digital sebagai acuan peserta didik dan referensi digital yang terintegrasi dengan pembelajaran, 4) Tidak meratanya sarana dan prasarana pendukung dan rendahnya pemahaman tentang teknologi, 5) Diperlukan strategi pembelajaran oleh pengajar untuk memaksimalkan potensi. Kelebihan bimbel tatap muka yaitu 1) Interaksi untuk membentuk suatu hubungan sosial dan kepercayaan lingkungan, 2) mempunyai jadwal belajar yang pasti, kekurangan bimbel tatap muka keterbatasan waktu sehingga pengajar tidak dapat melaksanakan diskusi yang mendalam sesuai dengan keinginan peserta didik (Widiara, 2018:50).

Dalam hal ini betapa pentingnya motivasi belajar siswa dalam suatu tempat bimbel. Karena bimbel yang sesuai dengan motivasi belajar siswa akan mampu membimbing belajar siswa dengan baik. Karena motivasi belajar siswa merupakan salah satu menentukan bagaimana mereka akan menjalani proses pembelajaran mereka di sekolah. Bimbel yang 
tidak sesuai dengan motivasi belajar peserta didik akan membuat mereka malas belajar dan kurang aktif dalam pembelajaran di sekolah maupun di luar sekolah, jika mereka menempatkan diri dalam bimbel yang tepat, motivasi mereka akan sangat bagus di sekolah maupun diluar sekolah.

Berdasarkan hasil wawancara di SMA Negeri 1 Kota Bengkulu yang dilakukan pada guru BK disekolah SMA Negeri 1 Kota Bengkulu saat sebelum menyusun proposal penelitian. Banyak peserta didik yang mengikuti bimbel diluar sekolah dengan berbagai tipe bimbel, seperti yang diketahui peserta didik yang mengikuti bimbel banyak tetapi nilai yang mereka dapatkan masih sama dan tidak ada perubahannya, dan ada juga beberapa siswa yang mendapatkan perubahan dari hasil bimbelnya.

Berdasarkan penjelasan di atas peneliti tertarik untuk meneliti apakah motivasi belajar siswa ada perbandingan antara belajar dengan bimbel tatap muka dan belajar melalui bimbel daring dengan aplikasi ruang guru sehingga hasil dari penelitian ini dapat diimplikasikan terhadap layanan bimbingan dan konseling di sekolah. Untuk itu peneliti merasa perlu meneliti tentang motivasi belajar dengan judul "Perbandingan Motivasi Belajar Siswa Antara Belajar melalui Bimbel Tatap Muka dan Belajar Melalui Bimbel Daring dengan Aplikasi Ruang Guru di SMA N Kota Bengkulu”.

\section{METODE PENELITIAN}

Desain penelitian ini menggunakan desain penelitian deskriptif komparatif dengan pendekatan kuantitatif. Komparatif adalah kesimpulan sementara yang menunjukkan adanya perbedaan dari satu atau beberapa kelompok sampel dalam suatu hasil pengukuran variabel yang sama sedangkan kuantitatif adalah data yang berbentuk angka (Mulyatiningsih, 2012). Penelitian ini bertujuan untuk membandingkan motivasi belajar siswa dengan bimbel tatap muka dan belajar bimbel daring dengan melalui aplikasi ruang guru di SMA Negeri 1 Kota Bengkulu.

Populasi adalah seluruh data yang menjadi perhatian penelitian dalam suatu ruang lingkup dan waktu yang ditentukan (Zuriah, 2009: 116). Populasi dalam penelitian ini adalah seluruh siswa jurusan XII IPA, XI IPA, XII IPS, dan XI IPS SMA Negeri 1 Kota Bengkulu. Populasi penelitian ini sebanyak 595 siswa.

Sampel adalah subset atau bagian dari jumlah dan karakteristik yang dimiliki oleh populasi tersebut (Sugiyono, 2010 : 118). Dalam penelitian ini akan diambil dengan menggunakan teknik random sampling, dengan jumlah 239 siswa. Peneliti memberi hak yang sama kepada setiap subyek untuk memperoleh kesempatan dipilih menjadi sampel. 
Selanjutnya, untuk menentukan ukuran sampel dari suatu populasi dapat menggunakan bermacam-macam cara, salah satunya yaitu dengan cara rumus slovin yaitu ukuran sampel merupakan perbandingan ukuran populasi terhadap persentase kelonggaran ketelitian dikarenakan kesalahan pengambilan sampel yang masih dapat ditolerir atau diinginkan.

Dalam penelitian ini syarat uji validitas yang digunakan adalah $>0,03$ jika di bawah 0,03 maka item tersebut dinyatakan gugur. Dari 38 angket yang disebarkan sebanyak 6 item yang gugur dan menyisakan 32 item valid. Apabila instrument sudah dinyatakan valid, maka angket tersebut akan digunakan sebagai alat ukur untuk mengukur motivasi belajar siswa. Uji validitas adalah indeks yang menunjukkan sejauh mana suatu alat pengukuran dapat dipercaya atau dapat diandalkan (Zuriah, 2009 : 192). Suatu instrument yang valid mempunyai validitas tinggi. Sebaliknya instrument yang kurang valid berarti memiliki validitas rendah.

\section{HASIL DAN PEMBAHASAN}

Tabel 1

Deskripsi hasil Angket Motivasi Belajar

\begin{tabular}{cc}
\hline Deskripsi & Jumlah \\
\hline Jumlah Sampel $(\mathrm{N})$ & 239 \\
Skor Minimum & 38 \\
Skor Maximum & 152 \\
Rata-Rata $(\mu)$ & 95 \\
Standar Devisiasi $(\sigma)$ & 14 \\
\hline
\end{tabular}

Dari hasil tabel di atas dapat diketahui sampel angket motivasi belajar berjumlah 239 dengan skor minimum 38 dan skor maximum 152. Pengisian angket motivasi belajar menghasilkan jumlah rata-rata sebesar 95, dengan standart deviasi 19.

\section{Tabel 2}

Uji Normalitas Data Angket Motivasi Belajar

\begin{tabular}{lcc}
\hline Aspek & Asymp. Sig. (2-tailed) & Distribution \\
\hline Motivasi Belajar & 0,021 & Normal \\
& & \\
\hline
\end{tabular}

Uji normalitas digunakan untuk menguji apakah data penelitian berdistribusi normal atau tidak (Ghozali, 2011). Untuk mendeteksi kenormalan data, digunakan uji One Sample Kolomogrov-Smirnov Test. Data yang berdistribusi normal memiliki p-value > 0,05, 
sebaliknya data yang berdistribusi tidak normal memiliki p-value $<0,05$. Hasil pengujian data normalitas dapat dilihat pada tabel berikut ini. Berdasarkan tabel di atas terlihat bahwa p-value (Asymp. Sig) > 0,05 yaitu 0,200>0,05 dengan demikian dapat disimpulkan bahwa data penelitian berdistribusi normal.

Tabel 3

Independent Sampel T- Test

\begin{tabular}{ccc}
\hline Aspek & T & sig ( 2-tailed) \\
\hline Motivasi Belajar & 4,775 & 0,000 \\
\hline
\end{tabular}

Berdasarkan hasil pengujian hipotesis tersebut diketahui bahwa bimbel tatap muka dan bimble daring melalui aplikasi ruang guru memiliki nilai signifikan dua arah 0,00 yang berarti $p$-value (Asymp. Sig) < 0,05. Sehingga diperoleh kesimpulan bahwa ho ditolak dan ha diterima, yakni terdapat perbedaan yang signifikan antara bimbel tatap muka dan bimbel daring melalui aplikasi ruang guru.

Penelitian ini membahas tentang perbandingan motivasi belajar siswa antara belajar dengan bimbel tatap muka dan belajar melalui bimbel daring dengan aplikasi ruang guru. Penelitian ini menggunakan metode deskriptif komparatif, data yang diperoleh dalam penelitian ini melalui melalui angket yang disebar secara online dengan menggunakan google form.

Berdasarkan data yang diperoleh, diketahui gambaran motivasi belajar siswa antara belajar dengan bimbel tatap muka dan belajar melalui bimbel daring dengan aplikasi ruang guru di SMA Negeri 1 Kota Bengkulu yang memiliki motivasi belajar rendah sebanyak 11 orang $(4,6 \%)$, subjek yang memiliki motivasi belajar sedang sebanyak 194 orang $(81,1 \%)$, dan subjek yang memiliki motivasi tinggi sebanyak 34 orang $(14,2 \%)$ dan dapat dikatakan dalam gambaran kategorisasi motivasi belajar berada pada kategori sedang. Berdasarkan hasil penelitian yang telah dilakukan tersebut dapat disimpulkan bahwa terdapat motivasi belajar yang signifikan antara bimbel tatap muka dan bimbel daring melalui aplikasi ruang guru.

Adapun keterbatasan penelitian ini adalah Penelitian dilakukan pada saat mendekati masa ujian semester, sehingga bekerjasama dengan guru BK untuk menentukan jadwal pembagian angket ke siswa agar tidak mengganggu belajarnya. Peneliti melakukan penyebaran angket secara online kepada siswa dengan melalui whatsapp. Peneliti harus menunggu karena siswanya ada yang tidak langsung mengisi. Adanya siswa yang tidak 
mengisi, peneliti langsung mengechat siswanya secara pribadi di whatsapp. Peneliti juga menyadari adanya keterbatasan saat penelitian pada masa pandemi covid ini, cakupan sampel penelitian terbatas hanya di kelas XI IPA, XII IPA, XI IPS, dan XII IPS SMA Negeri 1 Kota Bengkulu.

\section{KESIMPULAN}

Gambaran motivasi belajar siswa yang belajar melalui bimbel tatap muka peneliti melihat dari tabel perhitungan skor angket motivasi belajar dengan indikator intrinsik dan ekstrinsik. Uji hipotesis motivasi belajar dan bimbel tatap muka dengan bimbel daring melalui aplikasi ruang guru memiliki signifikan dua arah 0,00 yang berarti $p$-value (Asymp. Sig) $<0,05$.

Berdasarkan penelitian yang telah dilaksanakan, saran yang dapat diberikan peneliti adalah Siswa dapat memilih yang mana baik untuk motivasi belajar. Perbandingan motivasi belajar dapat membantu siswa dalam memberikan arah yang mana yang baik untuk pembelajarannya. Siswa di generasi millennial dapat memanfaatkan smartphone untuk memotivasi belajarnya, dengan kemajuan teknologi dapat membuat siswa mengembangkan motivasi belajar yang sesuai dengan dirinya. Sehingga siswa dapat belajar dengan baik di sekolah maupun di luar sekolah.

\section{DAFTAR PUSTAKA}

Agustini, A., Irwan, M., \& Khairurahimin. (2017). Pembelajaran Online Sebagai Solusi Belajar Biologi di Zaman Milenial Online Learning as a Solution to Learning Biology in the Millennial Age. Prosiding Seminar Nasioal Biologi VI Ariani, 2(1), 174-179.

Arimbawa, P. A., Santyasa, I. W., \& Rapi, N. K. (2017). Strategi Pembelajaran Guru Fisika: Relevansi dalam Pengembangan Motivasi Belajar dan Prestasi Belajar Siswa. Wahana Matematika Dan Sains: Jurnal Matematika, Sains, Dan Pembelajarannya, 11(1), 4360.

Elsap, D. S. (2018). Analisis Faktor Yang Mempengaruhi Peningkatan Karakter Dan Motivasi Belajar Anak Melalui Pendidikan Non Formal (Studi Kasus Di Bimbingan Belajar Aljabar). Jurnal Pendidikan Nonformal, 13(2), 85-91.

Emda, A. (2017). Kedudukan Motivasi Belajar Siswa Dalam Pembelajaran. Lantanida Journal, 5(2), 93-196. https://doi.org/10.22373/lj.v5i2.2838

Muhasim. (2017). Pengaruh Tehnologi Digital terhadap Motivasi Belajar Peserta Didik. Palapa: Jurnal Studi Keislaman Dan Ilmu Pendidikan, 5(2), 53-77. https://doi.org/10.36088/palapa.v5i2.46 
Putri, N. P. (2017). Eksistensi Bahasa Indonesia Pada Generasi Millennial Nimas. Widyabastra, 05(1), 45-49.

Setiawati, N. S. R. dan Mia. (2019). Aplikasi Pendidikan Online "Ruang Guru" Sebagai Peningkatan Minat Belajar Generasi Milenial Dalam Menyikapi Perkembangan Revolusi Industri 4.0. Seloka: Jurnal Pendidikan Bahasa Dan Sastra Indonesia, 3(2), 241-246. https://doi.org/10.1007/s11010-011-1216-4

Silondae, D. P. (2019). Perbandingan Motivasi Belajar Siswa Jurusan IPA dan IPS di SMA Negeri I Krueng Barona Jaya. Gema Pendidikan, 26(2), 1-9.

Siregar, H. I. (2016). Pengelolaan Metode Tutor Sebaya Dalam Meningkatkan Motivasi Belajar Siswa Pada Pembelajaran Microsoft Excel Di Kelas Viii-D SmpNegeri1Batangkuis.JurnalHandayani(JH),6(1),49-60. https://doi.org/10.1017/CBO9781107415324.004.

Sugiyono.(2010) Metode Penelitian Pendidikan. Bandung: Alfabeta.

Syafril, E. P. E. (2019). "Ruan gguru", Digitalisasi Pendidikan Antara Capaian NilaidanPengembanganKarakterMelaluiInteraksiSosial.Icadecs.Um.Ac.Id,9499.http:/ /icadecs.um.ac.id/wpcontent/uploads/2019/05/16-Elsa-Putri-Ermisah-Syafril.pdf

Syamsurijal. (2019). Artikel Survey Kepuasaan Siswa Yang Berlangganan Bimbingan Belajar Online Ruang Guru. Pernik Jurnal PAUD, 2(1). https://doi.org/10.30872/jim.v10i1.20

Wahana, H. D. (2015). Pengaruh Nilai-Nilai Budaya Generasi Millennial Dan Budaya Sekolah Terhadap Ketahanan Individu (Studi Di SMA Negeri 39, Cijantung, Jakarta). Jurnal Ketahanan Nasional, 21(1), 14. https://doi.org/10.22146/jkn.6890

Widiara, I. K. (2018). Blended Learning Sebagai Alternatif Pembelajaran di Era Digital. Purwadita, 2(2), 50-56.

Zuriah, N. (2009). Metodelogi Penelitian Sosial dan Pendidikan Teori Aplikasi. PT.Bumi Aksara. 